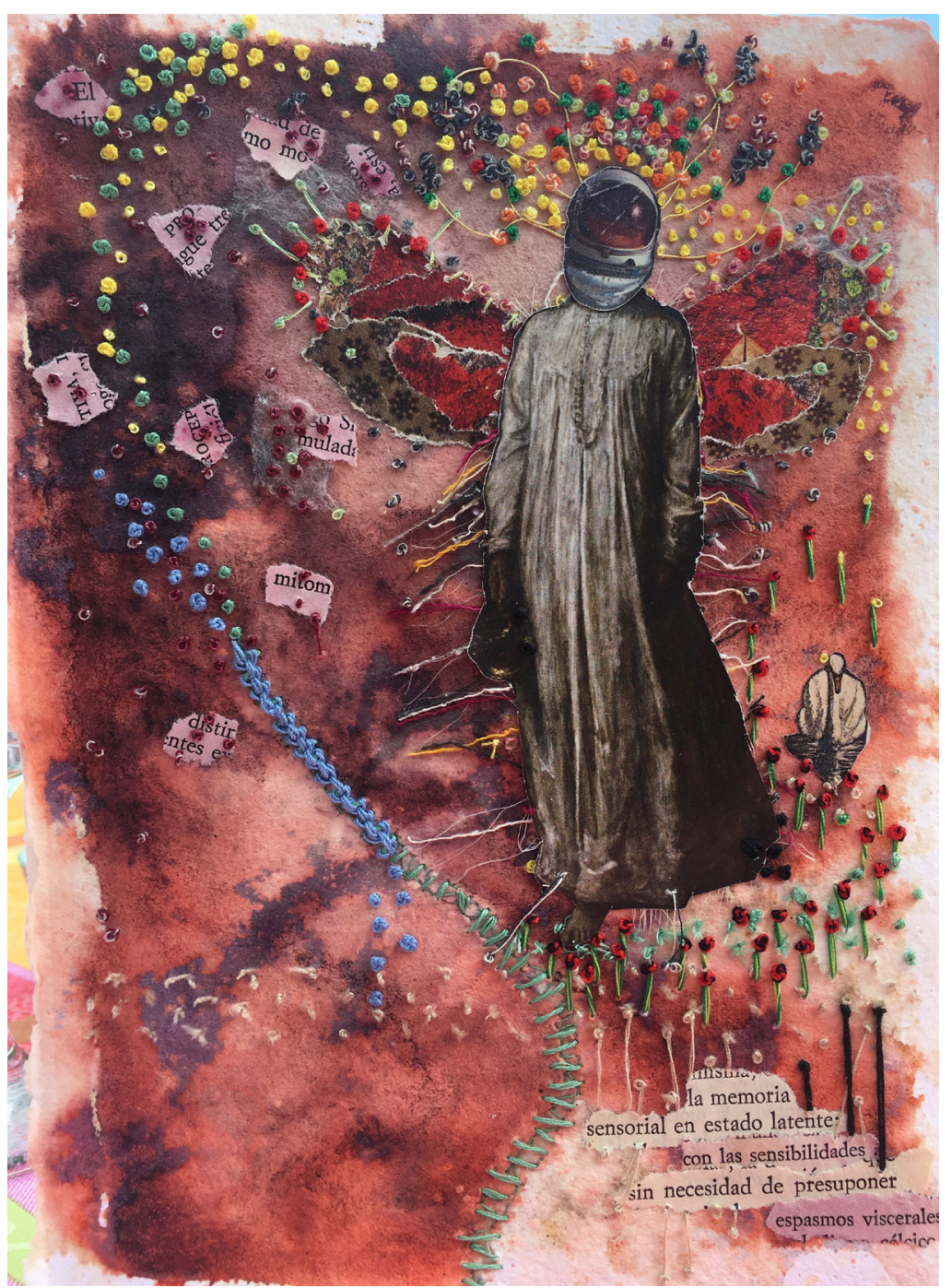

\title{
Mujer sonámbula astronauta
}

\section{Técnica}

Técnica mixta. Bordado sobre papel, collage y pigmento cochinilla.

\section{Reflexión}

La mirada velada por el miedo, el cual ya estaba a la vuelta de la esquina.

Tu verdad y la mía, al igual que el sueño interrumpido, fueron derrumbadas.

Fue inútil buscarlas de nuevo.

La quimera era ahora pesadilla de la que intentaba salir en vano.

Y nuevamente de forma insospechada... realidades nuevas,

o mentiras quizás, han sido imaginadas.

\section{Autora}

Norma Irene García Reyna. Titular de ATe y acreditada FEAPA.

Dra. en Psicología (UAB) y Arteterapeuta. Aplicaciones Psicoterapéuticas de la Práctica Artística (UB).

Arteterapia: papeles de arteterapia y educación artística para la integración social. Monográfico: Las miradas del arte y el arteterapia en tiempos de la Covid19. ISSN-e: 1988-8309 https://dx.doi.org/10.5209/arte.75906 